5. Ковтун А., Татарченко Л. Гендерні особливості мотивації студентів до занять фізичною культурою і спортом. Спортивний вісник Придніпров'я. 2018. № 2. С. 44-49.

6. Круцевич Т.Ю., Безверхня Г.В. Рекреація у фізичному вихованні різних груп населення. Київ: Олімпійська л-ра, 2010. 200 с.

7. Круцевич Т.Ю., Захарченко М.О., Марченко О.Ю. Врахування гендерного підходу в процесі занять з фізичного виховання учнівської молоді. Молодий вчений. 2017. № 3.1 (43.1). С. 180-183.

8. Круцевич Т., Марченко О., Імас Т. Проблема гендеру у фізичному вихованні дітей, підлітків і молоді. Фізичне виховання, спорт і культура здоров'я у сучасному суспільстві. 2015. № 3(31). C. 144-146.

\title{
DOI https://doi.org/10.30525/978-9934-26-044-5-15
}

\section{ОЗДОРОВЧЕ ЗНАЧЕННЯ ПЛАВАННЯ ДЛЯ МАЛЮКІВ РАННЬОГО ВІКУ}

\author{
Козуб С. В. \\ методист, керівник фізичного виховання
}

ВСП «Фаховий коледж харчових технологій та підприємництвва Дніпровського державного технічного університету»

\author{
Пойда В. Ю. \\ студентка II курсу
}

ВСП «Фаховий коледж харчових технологій та підприємництва Дніпровського державного технічного університету» м. Кам'янське, Дніпропетровська область, Украӥна

Актуальність. Фізичне виховання здійснюється у тісному зв'язку з розумовим, моральним, естетичним вихованням, займає одне 3 найважливіших місць у підготовці дітей до самостійного життя, виховує рухову грамотність та особистісні якості, сприяє соціальній адаптації та інтеграції в суспільство. Плавання в системі фізичного виховання визначається перед усім його важливим оздоровчим значенням і доступністю для людей різного віку.

Плавання - це ще один урок життя, який потрібно пройти кожному. Немає людей, що не можуть навчитися плавати, потрібно лише знайти правильну методику. Плавання - дуже корисне заняття, 66 
але завжди варто підходити до занять обережно, з особливою увагою, коли мова йде про раннє плавання для малюків.

Раннє плавання для малюків - це перш за все корисна практика фізичного розвитку. Основа фізичного розвитку закладається в ранньому віці, вчені довели, що регулярне плавання в басейні на 95\% поліпшує функцію мозку та фізичний розвиток немовляти. У таких дітей краще розвивається дихальна система легенів, міцнішають суглоби та хребет, формуються задатки гарної постави. А також маленькі плавці сильніші та витриваліші за своїх однолітків, які не відвідували басейн у ранньому віці.

Після дев'яти місяців внутріутробного життя водна стихія знайома малюкові, тому вважається, що в воді він відчуває себе дуже комфортно, відчуває звичне середовище, у якому дуже добре почувається. Але складно порівнювати навколоплідні води 3 басейном. Це помилка вважати, що дитині з народження подобається вода і тому його можна занурювати в воду без підготовки. До народження малюка в навколоплідних водах було тісно, тепло, затишно і спокійно, він чув стукіт маминого серця. Занурення в воду - це стрес для дитини, тому раннє плавання пом'якшує цей стрес, допомагає дитині адаптуватися, пізнати водне середовище заново, розвинути любов до води. Плавання для малюків - це не тільки і не стільки навчання дітей плаванню, скільки особлива методика розвитку малюків, яка націлена на розширення зони комфорту дитини і надання йому можливості відчути себе однаково сильним, впевненим і вільним у будь-якої стихії.

Раннє плавання або плавання для малюків оповите серпанком чуток і міфів. Багато мам 3 жахом в очах розповідають про брудні басейни, холодні роздягальні, загостреннях дерматиту та звірства інструкторів, які буквально силоміць змушують малюків пірнати i надовго затримувати дихання. Однак останні дослідження говорять про те, що всі ці жахливі, на думку батьків, обставини насправді сприяють суттєвому зміцненню дитячого імунітету, а також активізують психологічний та соціальний розвиток дитини. Імунологи всього світу стверджують, що відвідування басейну зміцнює імунітет і $є$ відмінною профілактикою застуди. Безумовно, такі заняття вкрай сприятливо впливають і на апетит, i на сон, і на загальний режим дня.

Спільні 3 батьками тренування дають змогу дитині добре розслабитися у воді, отримати позитивні емоції та енергетичний заряд. У деяких спортивних клубах існують індивідуальні заняття, це один із варіантів займатися раннім плаванням. Батьки приносять дитину, віддають інструктору, він займається, а вони з бортика чи за склом спостерігають. Звичайно, тут багато плюсів для батьків: руки їх вільні, не потрібна довідка, можна знімати своє дитя з різних ракурсів. Але! Не кожна дитина згодна йти до інструктора. Більшість дітей легше 
адаптується до нового середовища та активності з рідною людиною у воді. Для батьків - це проведення корисного часу разом з малюками, можливість вивчити нові рухи та вправи, відчувати свою дитину у власних обіймах, ознайомитися із тим, як і що робити з малюком у воді вдома, у ванні. Чим активніше веде себе мама, тим фізично більш активною буде дитина. Такі висновки зробили британські вчені i рекомендували покращувати здоров'я дітей, змінюючи спосіб життя дорослих. Навряд чи можна виховати геніальну, здорову і всебічно розвинену дитину, закрившись 3 нею в чотирьох стінах. Для дитячого організму, який росте i розвивається, плавання для немовлят рекомендується 3 перших днів життя. Методики, якими володіє професійний тренер, безпечні і перевірені роками практики. Сучасні батьки не чекають, поки дитина піде в школу, вони знаходять сертифікованого акватренера i хороший басейн, ще до народження малюка.

Малюки не можуть багато рухатися, а у воді вони отримують помірне фізичне навантаження, яке сприяє розвитку зниження, властивого немовлятам перших місяців життя, підвищеного тонусу згинальних м'язів, що забезпечує прискорене формування рухових умінь малюка. Сила м'язів зростає, дитина стає міцнішою та 3 віком дитина краще за інших відчуває своє тіло та вміє контролювати його. Плавання сприяє розвитку всього опорно-рухового апарату. Багато експертів називають цей вид спорту найкращим, у якому є можливість, майже без травм тренувати всі групи м'язів організму. Особливо розвивається плечовий пояс, а також інші м'язи - рук, ніг, преса тощо. Для дитяти, яке швидко зростає, - це дуже важливо.

Раннє плавання допомагає засвоїти правильне глибоке дихання. Багато дітей хворіють, як зазначають лікарі, через те, що неправильно дихають. Під час поверхового дихання легені повністю не очищуються, тому часто «чіпляється» будь-яка інфекція та швидко поширюється організмом. Правильно поставлене дихання - прекрасне тренування для дихальної мускулатури, дозволяє збільшити об'єм легенів, підвищити силу i тонус дихальних м'язів, збільшити стійкість організму до гіпоксії. Насичення киснем безпосередньо впливає на роботу мозку. У воді відмінно тренуються легені, адже коли вона тисне на грудку i животик малюка, створюється природне i оптимальне навантаження на дихальну систему. Приблизно до 5 місяців у дитини ще зберігається рефлекторна затримка дихання, яка також сприяє активному розвитку легенів. Дитина, яка плаває, навчається глибоко дихати, аждже максимальне споживання кисню позитивно впливає на роботу мозку, тому такі діти легко сприймають інформацію і в майбутньому навчаються без проблем. 
Плавання для малюків добре загартовує дитячий організм. Як відомо, загартовування - це доступний спосіб підвищити опірність організму до вірусів, зміцнити здоров'я і розвинути здатність тіла пристосуватися до температурних змін без стресу і негативних наслідків. Це не панацея від усіх хвороб, але загартовування організму дитини дозволить зменшити частоту захворювань, а укріплений імунітет зможе швидше впоратися 3 вірусами. У басейні відбувається природне загартовування організму, секрет якого полягає в спеціальному температурному режимі. Для немовлят температура води становить $+34^{\circ} \mathrm{C}$, а температура повітря в приміщеннях та роздягальнях до $+24^{\circ} \mathrm{C}-$ завдяки такій різниці температур дитячий організм загартовується. У результаті діти раннього віку перестають хворіти на простудні захворювання і менше схильні до ГРВІ. Спочатку в дитини можуть активуватися простудні хвороби, але не слід лякатися та залишати плавання, вилікуйте маля та йдіть знову. Мине час адаптації, дитина зовсім припинить хворіти.

Плавання для малюків - це не тільки вміння триматися на воді, не тільки оздоровлення і загартовування організму, - це, перш за все, спілкування та розвиток емоційного інтелекту і отримання насолоди, дієва методика всебічного розвитку малюка.

\section{Література:}

1. Булатова М.М., Плавание для здоровья. Булатова М. М. / К.П.Сахновский. - Киев, Знання 1998.

2. Омельченко С.О. Взаємодія соціальних інститутів суспільства у формуванні здорового способу життя дітей та підлітків: монографія. Луганськ: Альма-матер, 2007.

3. Мухортова Е.Ю. Обучение плаванью малышей: метод. пособие для инструкторов по физ. культуре (плавание), педагогов дошк. Образо ват.учреждений и родителей/ Е. Ю. Мухортова. - М.: ФиС,2008

4. Мухин В. Н. Плавание - здоровье детей / В. Н. Мухин, Ю. И. Радыгин. - Киев: Здоров’я, 1988.

5. Федулова А., Раннее плавание для малышей, новорожденные и груднички/А.Федулова. -М. :интелектик, 2011. 